\title{
PHANEROZOIC VEINS OF GALENA IN THE ÅLAND RAPAKIVI AREA, SOUTHWESTERN FINLAND
}

\author{
LEIF BERGMAN and BO LINDBERG
}

\begin{abstract}
BERGMAN, LEIF and LINDBERG, BO 1979: Phanerozoic veins of galena in the Alland rapakivi area, southwestern Finland. Bull. Geol. Soc. Finland 51, 55-62.

Some minor galena mineralizations are in part associated with clastic dykes of Cambrian sandstone in the Aland rapakivi area. Galena also occurs disseminated in greisen-type mineralizations. The difference in age between the two modes of occurrence is probably at least $1100 \mathrm{Ma}$.

No traces of a magmatic source have been found, and hence, a magmatic-hydrothermal origin for the galena associated with sandstone dykes is unlikely. It is suggested that the lead-bearing solutions mobilized from the sediments and precipitated in fissures during compaction and diagenesis.
\end{abstract}

Leif Bergman and Bo Lindberg, Geologisk-mineralogiska institutionen, Abo Akademi, SF-20500 Abo 50, Finland.

\section{Introduction}

There are several minor sulphide mineralizations with galena as the predominant ore mineral in the Finnish rapakivi areas and their immediate vicinity (O. Vaasjoki 1956, M. Vaasjoki 1977). Galena occurs within the rapakivi areas either associated with postmagmatic greisens or as younger veins (M. Vaasjoki 1977, p. 42).

The galena mineralizations in the Aland rapakivi area differ from those in the other rapakivi areas in that the veins in part occur together with clastic dykes of Cambrian sandstone.

The occurrences associated with sandstone dykes on Silverskär, Långholm, Ådö, and Loören (Fig. 1) are discussed in detail in this paper. The galena mineralizations in connection with greisen, as in Grelsby (Fig. 1) where the galena is disseminated in a sericite greisen, are not described further.

The mineralizations at Grelsby and Silverskär have been known since the 17 th century (Radloff 1795, Pehrman 1948). The galena veins on Loören have long been familiar to the local people and are mentioned by M. Vaasjoki (1977) and Ehlers and Ehlers (1979). The occurrences on Långholm and Ådö were found during recent investigations in the rapakivi area. From Långbergsödaöjen (Fig. 1) and its vicinity veins of galena are mentioned 


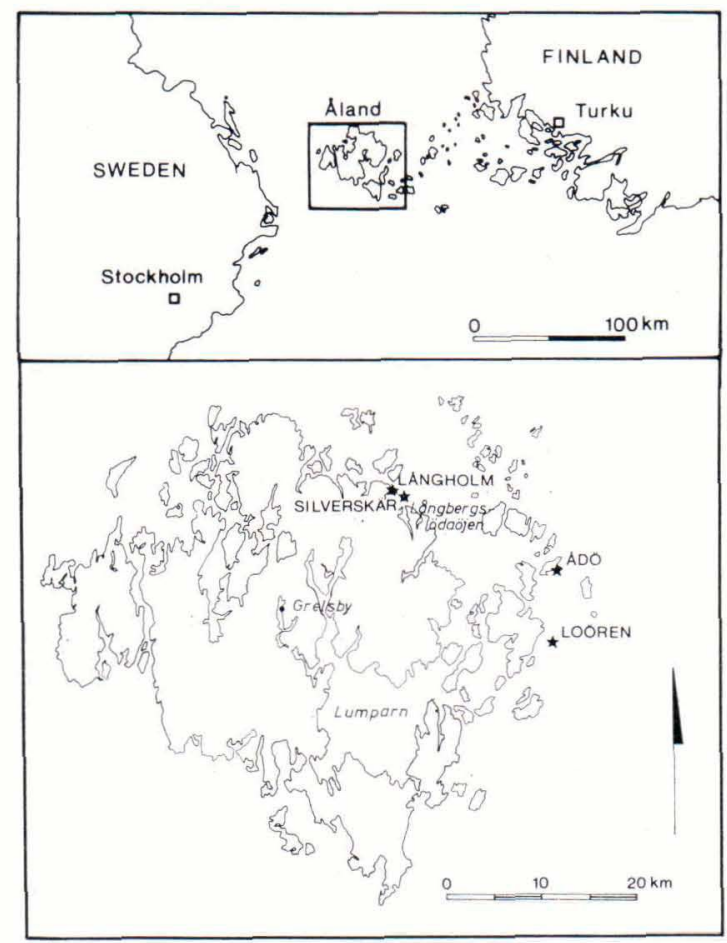

Fig. 1. Map of the Aland area showing the locations of the galena occurrences.

by Frosterus and Sederholm (1890) and Mattsson (1960).

East of the rapakivi area veins of galena have been found on Södö, Sottunga (Frosterus 1894) and on the southwestern shore of Kökar (Carl Ehlers 1978, Åbo, personal comm.). The galena occurrences of Grelsby, Silverskär and Södö have been briefly described by IM. Vaasjoki (1977, App. 2). Veins of galena, mostly associated with calcite (Åhman 1974), occur along the Swedish coast of the Aland Sea and in the Stockholm region.

\section{Outlines of the geology}

The Aland rapakivi area

The rapakivi area consists of several texturally and mineralogically different granite varieties, from normal rapakivi with feldspar ovoids, to fine-grained aplitic and quartz porphyritic granites. Ages determined from the rapakivi area indicate two different phases of intrusion: $1670 \mathrm{Ma}$ for the main rapakivi intrusions and $1620 \mathrm{Ma}$ for the younger ones (M. Vaasjoki 1977, p. 26).

Postmagmatic greisen bodies occur principally in connection with the younger granites, but they have been found sporadically in the whole rapakivi area. The greisens are poorly mineralized, and ore minerals are scarcely visible to the unaided eye. The lead content, although randomly distributed in the greisens, is higher in the northern and eastern part of the rapakivi area.

\section{Phanerozoic rocks}

During our remapping of the rapakivi area in Alland in 1972-77 we added some 250 new sandstone dykes to those known there since the 19th century (Frosterus and Sederholm 1890). Several sandstone dykes, one of the fossiliferous, have been described by Tanner (1911) from the northeastern shore of the Långbergsödaöjen peninsula. Pyrite occurs as concretions in one of them and as

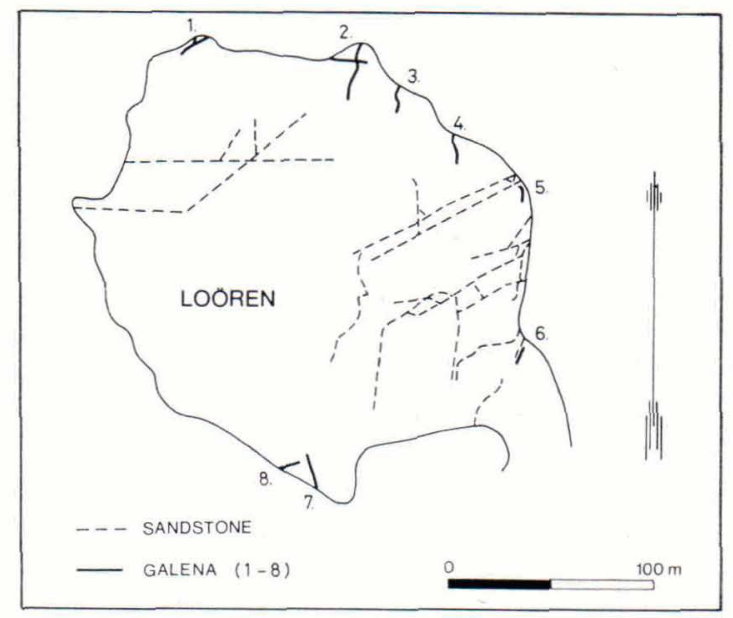

Fig. 2. Galena veins and sandstone dykes on Loören. 
cement in another. The cementing pyrite forms a replacement border 4 to $6 \mathrm{~mm}$ wide on both sides of the sandstone dyke. According to Martinsson (1968, p. 144), also galena occurs frequently in some sandstones from this locality.

The age of the sandstone dykes was determined as Lower Cambrian on the basis of the brachiopod Acrotreta tanneri found in the fossiliferous sandstone dyke from Långbergsödaöjen (Tanner 1911, Metzger 1922). Re-examination of the brachiopod Ceratreta tanneri according to the new nomenclature - indicates an Upper Cambrian age (Martinsson 1968).

The clastic dykes show that Aland was covered by sediments during the Cambrian and that the denudation before the Cambrian had reached approximately the present level of erosion (Tanner 1911). Sedimentation probably continued into the Ordovician, because limestone of Ordovician age has been found (Asklund and Kulling 1926, Sederholm 1934) in the northern part of Lumparn Bay (Fig. 1). Drilling shows that the limestone is $34 \mathrm{~m}$ thick and is underlain by clay (upper grey and lower reddish) to a depth of at least 57.5 m (Sauramo 1943, Martinsson 1956, p. 99). The difficulty of drilling, however, prevented complete penetration of the clay. According to Metzger (1960, p. 13, 1965, p. 151-152), the formation was traced by 24 later drill holes for about $2 \mathrm{~km}$ to the south, where it is underlain by sandstone. The sandstone has undergone much weaker diagenesis than the clastic dykes. Lumparn Bay is probably a graben that formed after the Ordovician (Hausen 1964, p. 52). Martinsson (1956, p. 100) has proposed an erratic origin for this limestone.

Erratic boulders of pyrite-cemented sandstone have been found on Aland and in southwestern Finland (Marmo and Laitakari 1952, Lonka and Papunen 1969). The source of the boulders is probably a Cambrian sandstone bed under the Bothnian Sea. The sandstone is covered by Ordovician limestone, with forms the floor of the western part of the Bothnian Sea (Winterhalter 1972).

\section{Description of localities}

\section{Loören}

Eight galena veins and a swarm of sandstone dykes have been encountered on Loören (Fig. 2). The galena veins are 0.2 to $1 \mathrm{~cm}$ wide, a few metres long and strike roughly N-S. Six of them consist of either pure galena (Nos. 2, 3 and 8) or have a gangue of very fine-grained silica (Nos. 1, 4 and 7). In veins Nos. 1 and 4 the galena has been split in two by fine-grained silica with abundant fragments of galena. The fragments have been torn away from the galena vein, which suggests small-scale movements at the time of crystallization of the silica. The surrounding rapakivi reveals microscopic cataclastic zones with undulatory quartz and minute fissures filled with silica and some galena. Vein No. 2, which is maximum $1 \mathrm{~cm}$ wide, can be traced from sea level, where it strikes about $30^{\circ}$, for a few metres until it crosses a narrow fracture zone striking $110^{\circ}$. At this point the vein is $5 \mathrm{~cm}$ wide and follows the fracture zone to the east for half a metre before it resumes its former course and width.

Two of the galena veins (Nos. 5 and 6) are associated with sandstone dykes. No. 6 was studied in more detail. At sea level it is a pure sandstone dyke, but some metres from the shore it grades into a sandstone dyke mineralized with pyrite, galena, marcasite, sphalerite and accessory chalcopyrite. The width of the sandstone dyke is 5 to $7 \mathrm{~cm}$. In the sandstone the cement, which is usually silica, has been replaced by sulphides, which have also partly corroded the sand grains. The quartz grains of the sandstone are sub- 


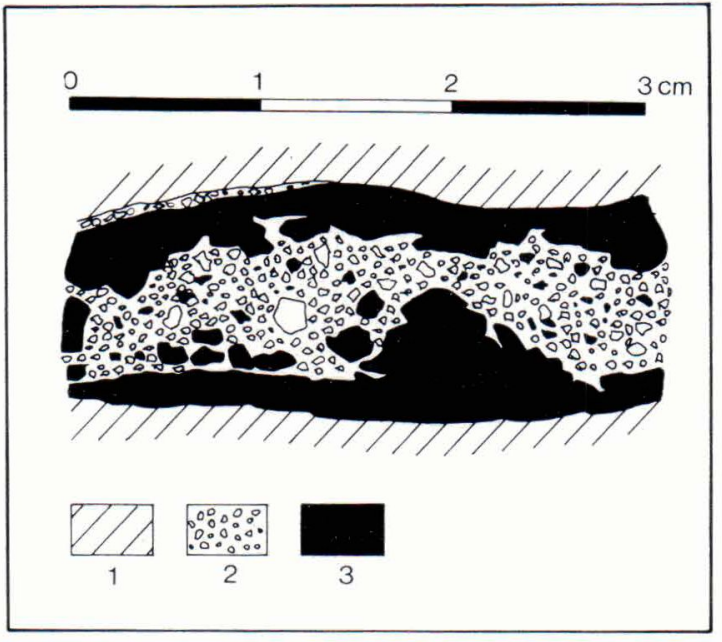

Fig. 3. Fissure filling of sandstone and galena. Note the thin clastic remnant in the upper left. 1) Rapakivi. 2) Sandstone. 3) Galena. Silverskär.

rounded, whereas the feldspar and rapakivi fragments are angular.

\section{Silverskär}

Silverskär has an old galena quarry dating from 1610. Located on the northern shore (Finnish map coordinates: $\mathrm{x}=6694.84, \mathrm{y}=$ 452.92), the quarry is about $30 \mathrm{~m}$ long, a maximum of $3 \mathrm{~m}$ wide and strikes $130^{\circ}$. Presumably only one galena vein was mined because at the southern end of the quarry there is a galena vein a few $\mathrm{mm}$ wide striking $160^{\circ}$ and at the northern end, on the shore, a vein 1 to $2 \mathrm{~cm}$ wide with a few offshoots 2 to $3 \mathrm{~mm}$ wide. Fig. 3 shows a detail of a drill core sample from the northern end. The galena vein is about $1 \mathrm{~cm}$ wide with remains of a sandstone dyke in the middle. A narrow remnant of the same sandstone dyke occurs along one of the contacts with rapakivi. Conceivably the sandstone has been fissured and galena has crystalized in the fissure. The galena has also crystallized between the sand grains, partly corroding them. Accessory sulphides are pyrite, marca- site and sphalerite. The sandstone is slightly recrystallized, but it still maintains a distinct clastic texture.

\section{Långholm}

On the northern shore of Långholm, about $1 \mathrm{~km}$ northwest of Silverskär, there is one dyke consisting of pure galena $(\mathrm{x}=6695.53$, $\mathrm{y}=451.71)$ and ten sandstone dykes striking $10^{\circ}-20^{\circ}$, one of which $(\mathrm{x}=6695.24, \mathrm{y}=$ 451.92) contains galena. The sandstone dyke associated with galena is up to $5 \mathrm{~cm}$ wide. Galena occurs at the margins of the sandstone dyke only south of the point where a minor fracture zone crosses it. Southwards the dyke bifurcates and the galena occurs mostly at the outer contact of the dyke.

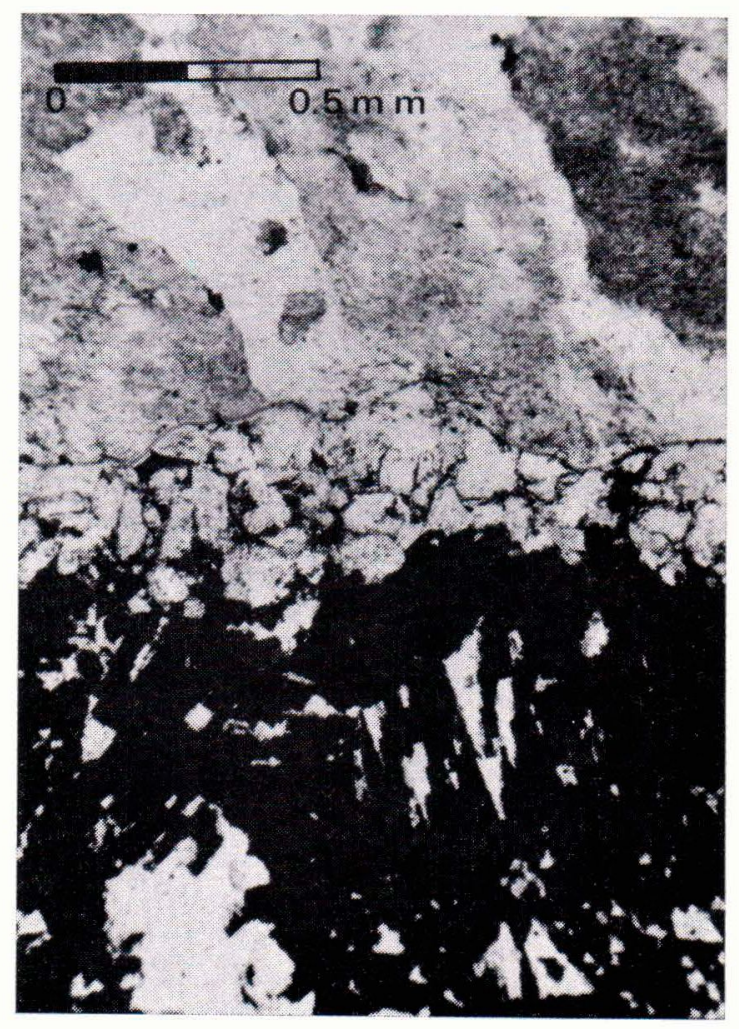

Fig. 4. Photomicrograph of the clastic remnant between rapakivi and galena in Fig. 3. Without nicols. 


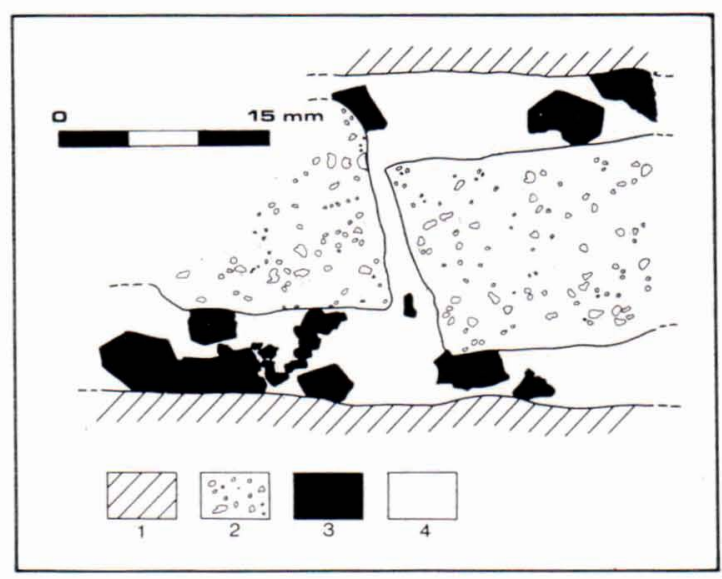

Fig. 5. Detail of a sandstone dyke. The fissure was reopened and slightly displaced after the lithification of the sandstone. Galena and fluorite have later crystallized in the same fissure. 1) Rapakivi. 2) Sandstone. 3) Galena. 4) Fluorite. Ådö.

Adö

A swarm of sandstone dykes 1 to $5 \mathrm{~cm}$ wide and calcite dykes $1 \mathrm{~cm}$ wide associated with galena and fluorite are encountered on the southern shore of the eastern point of Ådo $(\mathrm{x}=6688.33, \mathrm{y}=469.58)$. The dykes strike roughly $20^{\circ}$. The calcite dykes display idiomorphic crystals of galena in several places. One of the dykes clearly shows the age relation between sandstone and galena (Fig. 5). The sketch shows a section of the sandstone dyke, which has been fractured and partly displaced. Galena and fluorite have crystallized in the fracture. Galena and accessory pyrite also occur as narrow fracture filling or as small grains in the matrix of the sandstone. The sandstone is slightly recrystallized along the fluorite-galena contact but clastic texture can still be discerned. The recrystallization zone is 2 to $3 \mathrm{~mm}$ wide. The cementing material of the sandstone is ironpigmented silica except in one dyke where it is fluorite. In some localities in the Wiborg rapakivi area fluorite is also associated with galena (O. Vaasjoki 1956, p. 50).

\section{The age and origin of the galena}

Field obaservations indicate that there are two different types of galena mineralization in Aland:

1. Galena genetically associated with greisen;

2. Veins of galena associated with sandstone dykes.

The greisen bodies are considered to be associated in space and time with the youngest intrusion phases of the rapakivi granite complex, i.e. they are genetically linked to the rapakivi granites. Datings of rapakivi granites from Åland give ages of 1670-1620 Ma (M. Vaasjoki 1977, p. 26), which should also be the approximate maximum age of the galena occurrences associated with greisen.

As mentioned earlier, the sandstone dykes in Aland are probably Late Cambrian, i.e. they are about $500 \mathrm{Ma}$ old. As shown by Fig. 5 , the galena cuts across already lithified sandstone dykes, which means that it is Cambrian or younger. Hence, the difference in age between the two different types of galena occurrences is at least $1100 \mathrm{Ma}$.

M. Vaasjoki (1977) has made lead isotopic studies of the galena from Grelsby, Silverskär, Loören and Södö. The isotope compositions show that the galena from Grelsby differs from the others. It is the least radiogenic, and its age is $1362 \mathrm{Ma}$ (M. Vaasjoki 1977, Table 11, p. 50). According to Vaasjoki (1977, p. 51), its young age suggests contamination of the lead. The galenas from the other localities are anomalous as far as their modal ages are concerned. These ages are, however, relatively heterogenous and three age determinations from Loören show that they cannot be plotted on a straight line, not even within a single occurrence (M. Vaasjoki 1977, p. 51).

M. Vaasjoki (1977) suggests that the galena veins are of rapakivi age and derived from 


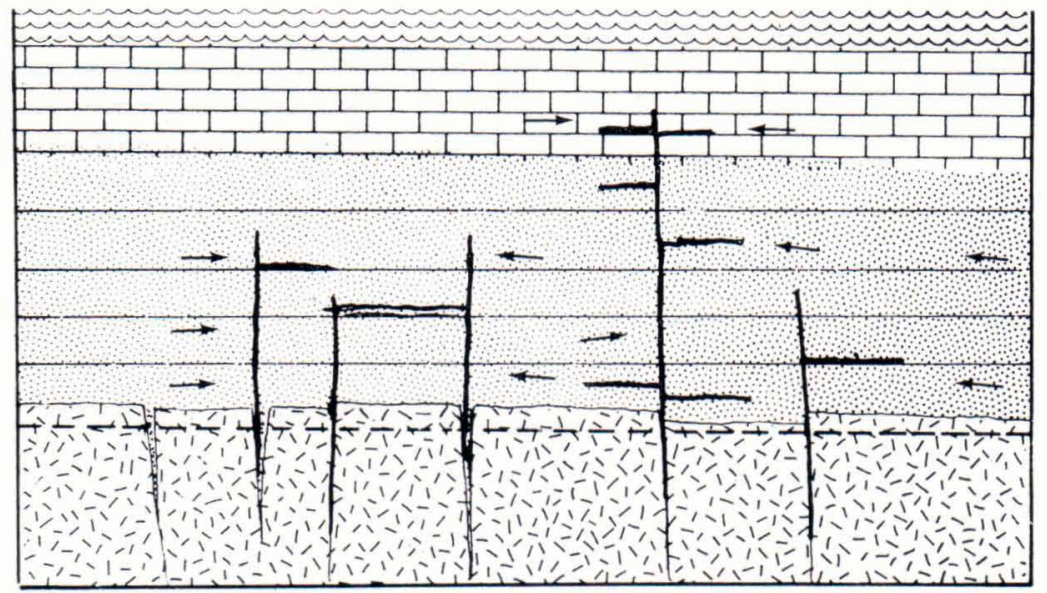

ORDOVICIAN LIMESTONE ?

CAMBRIAN SANDSTONE

\section{PRESENT EROSION} LEVEL

\section{RAPAKIVI}

Fig. 6. A model for the origin of the galena associated with Cambrian sandstone. The lead-rich solutions were mobilized out of the enclosing sediments during diagenetic processes, precipitating galena in fissures.

their host rock. For the galena veins on Silverskär, Långholm, Ådö and Loören this hypothesis would imply remobilization of the lead and precipitation in fissures during the Cambrian or later. In the light of the low content of base metals in the galena from Södö, O. Vaasjoki (1956, p. 52) stated that it "most probably belongs to post-tectonic fissure fillings, perhaps even younger than pre-Cambrian in age».

Galena mineralizations that partly resemble the occurrences in Aland are found in many places along the eastern margin of the Caledonides: some are of the disseminated type in Cambrian sandstone, others are galena veins within the Caledonides and in Precambrian rocks east of the mountain range (Grip 1967). The mineral composition is: galena, sphalerite, pyrite, baryte, fluorite and calcite, which would suggest a low temperature of formation. The galena generally contains a surplus of radiogenic lead (Grip 1967, p. 214-126).

Grip (1967) considers the galena mineralizations to be epigenetic and the ore-forming solutions to have originated from palingenetic processes in the central part of the mountain range. These solutions may have leached out radiogenic lead from overlying Cambrian shales and thus caused a surplus of radiogenic lead.

It is, however, less probable that processes at work within the Caledonian mountain range could have produced ore-forming solutions as far from the source as in the Aland area. If this mode of origin is to be assumed for the galena veins in Aland, the source must be much closer. Such magmatic sources are not known and, should they have ever existed, they would be relatively deepseated. The northern part of the Aland rapakivi area is cut from northwest to southeast by distinct tectonic fracture zones (Hausen 1948 and 1964) that are fairly close to the galena occurrences. Had there been Phanerozoic magmatic-hydrothermal activity these zones might have acted as feeding channels for ore-forming solutions.

One explanation for the forming of the galena veins may be the theory that the ore-forming fluid was pressed out of the Phanerozoic sediments (Fig 6). During the Cambrian, sand was mainly deposited and the sedimentation probably continued into 
the Ordovician. The diagenetic processes started in the lower parts of the sediments, causing lithification of the sand and migration of the water with its dissolved metals. At the same time, existing and new fissures opened and were filled with wet sand from unconsolidated layers above. Later leadbearing solutions infiltrated the clastic dykes, and galena was precipitated.

Noble (1963) stresses that water of compaction may have played an important role in the forming of sandstone-type vanadiumuranium deposits of the Colorado-Plateau and Mississippi-Valley-type lead and zinc deposits. Such waters can receive their metal content during the diagenesis of the enclosing sediments (Noble 1963, p. 1147).

\section{Conclusions}

Field observations in the Aland rapakivi area indicate the presence of minor galena mineralizations of two different ages:

\section{References}

Asklund, B. and Kulling, O. (1926) Nya data till Alands geologi. Geol. Fören. Stockh. Förh. 48, 498-511.

Ehlers, C. and Ehlers, M. (1979) Beskrivning till berggrundskartan 1023 Kumlinge. Geologisk karta över Finland, 1:100000. Geologiska forskningsanstalten, Esbo. (in print)

Frosterus, B. (1894) Beskrifning till kartbladet No 25 Föglö. Finl. Geol. Unders. 43 p.

- and Sederholm, J. J. (1890) Beskrifning till kartbladet No 17 Finström. Finl. Geol. Unders. $51 \mathrm{p}$.

Grip, E. (1967) On the genesis of the lead ores of the eastern border of the Caledonides in Scandinavia. Econ. Geol. Monogr. 3, 208-218.

Hausen, H. (1948) Ytgestaltningen i ÅbolandsÅlands skärgård och dess orsaker. Skärgårdsboken, 30-73. Nordenskiöld-samfundet i Finland.

- (1964) Geologisk beskrivning över landskapet Åland. Skrifter utgivna av Ålands kulturstiftelse IV. Mariehamn. $196 \mathrm{p}$.
1. Precambrian, of rapakivi age, $1620 \mathrm{Ma}$;

2. Cambrian or younger, $500 \mathrm{Ma}$ or less.

The Precambrian galena is associated with greisenization in rapakivi, but the Cambrian galena can hardly be genetically linked to the rapakivi granites because it has partly precipitated in the fissures occupied by Cambrian sandstone.

A sedimentary-chemical process for the origin of the galena is proposed. The leadbearing solutions are squeezed out of the sand during compaction and diagenesis, and galena is precipitated in the open fissures.

Acknowledgements - The authors express their thanks to K. H. Renlunds Stiftelse för Finlands praktisk-geologiska undersökning which has financed the investigation in the Aland rapakivi area. We are also grateful to prof. Nils Edelman and assistant prof. Carl Ehlers for reading the manuscript.

Miss Merja Kuusisto drew the maps and the sketches.

The manuscript was translated into English by Miss Carola Lindblad.

Lonka, A. and Papunen, H. (1968) Pyrite-bearing sandstone blocks, western Finland. Bull. Geol. Soc. Finland 40, 99-106.

Marmo, V. and Laitakari, A. (1952) Lounais-Suomen rikkikiisukonkreetioista (with an English summary: On the pyrite-concretions of southwest Finland). Geologinen tutkimuslaitos, Geoteknillisiä julkaisuja 53, $14 \mathrm{p}$.

Martinsson, A. (1956) Neue Funde kambrischer Gänge und ordovizischer Geschibe im südwestlichen Finnland. Bull. Geol. Inst. Uppsala $36,79-105$.

- (1968) Cambrian paleontology of Fennoscandian basement fissures. Lethaia 1, 137-155.

Mattsson, A. (1960) Sprickfyllnader och hällskulptur. Svensk Geografisk Årsbok 36, 85-105.

Metzger, A. Th. (1922) Beiträge zur Paläontologie des nordbaltischen Silurs im Ålandsgebiet. Bull. Comm. Géol. Finlande 56, 8 p.

- (1960) Geology of the archipelago of southwestern Finland. Excursion guide to Int. Geol. Congr. Norden. Helsinki, 20 p. 
- (1965) De kambriska lagren under Lumparn på Åland. Norsk Geol. Tidskrift 45, 151-152.

Noble, E. A. (1963) Formation of ore deposits by water of compaction. Econ. Geol. 58, 11451156.

Pehrman, G. (1948) Skärgårdens mineralförekomster. Skärgårdsboken, 95-103. Nordenskiöldsamfundet i Finland.

Radloff, F. W. (1795) Beskrifning öfver Åland. Åbo, $260 \mathrm{p}$.

Sauramo, M. (1943) En djupborrning genom silurkalksten i Lumparfjärden, Aland. Soc. Sci. Fennica, Commentat. Physico-Math. XI. 12, $1-4$.

Sederholm, J. J. (1934) On migmatites and associated pre-Cambrian rocks of southwestern Finland. Part III. The Aland Islands. Bull. Comm. Géol. Finlande 107, 68 p.

Tanner, V. (1911) Über eine Gangformation von fossilienführendem Sandstein auf der Halbinsel Långbergsödaöjen im Kirschspiel Saltvik, Aland Inseln. Bull. Comm. Géol. Finlande $25,13 \mathrm{p}$.

Vaasjoki, M. (1977) Rapakivi granites and other postorogenic rocks in Finland: their age and the lead isotopic composition of certain associated galena mineralizations. Geol. Surv. Finland. Bull. 294, 64 p.

Vaasjoki, O. (1956) A comparison of the minor base metal contents of some Finnish galenas. Bull. Comm. Géol. Finland 172, 47-53.

Winterhalter, B. (1972) On the geology of the Bothnian Sea, an epeiric sea that has undergone Pleistocene glaciation. Geol. Surv. Finland Bull. 258, $66 \mathrm{p}$.

Åhman, E. (1974) Några på senare tid upptäckta kalkspat/blyglansgångar i Stockholmstrakten. Geol. Fören. Stockh. Förh. 96, 405-410.

Manuscript received, April 2, 1979. 